Creative Commons User License: CC BY-NC-ND

Abstracted by: EBSCOhost, Electronic Journals Service (EJS), Google Scholar, Journal Seek, Scientific Commons,

Food and Agricultural Organization (FAO), CABI and Scopus
Journal of Agricultural Extension

Vol. 23 (4) October, 2019

ISSN(e): 24086851; ISSN(Print); 1119944X

http://journal.aesonnigeria.org

http://www.ajol.info/index.php/iae

Email: editorinchief@aesonnigeria.org

\title{
Effect of Value Addition on Farm Income of Sweet Potato Farmers in Kwara State, Nigeria \\ https://dx.doi.org/10.4314/jae.v23i4.11
}

\author{
Alalade, Oluwasegun Ayodeji \\ Extension Management Division, Department of Rural Development and Gender Issues, \\ Agricultural and Rural Management Training Institute (ARMTI), Ilorin, Nigeria. \\ segunalalade@gmail.com ., Phone: +2347063880416
}

\section{Oladunni, Olufemi Ajayi}

Extension Management Division, Department of Rural Development and Gender Issues, Agricultural and Rural Management Training Institute (ARMTI), Ilorin, Nigeria.

oaoladunni@armti.org..,Phone: +2348036672651

\section{Adisa, Rashid Solagberu}

Department of Agricultural Extension and Rural Development, University of Ilorin, Nigeria. rsadisa@unilorin.edu.ng ., Phone: +2348037523892

\section{Olayode, Oluwafunmilola Olawunmi}

Department of Agricultural Extension and Rural Development, University of Ilorin, Nigeria. wefocex@gmail.com., Phone: +2348062507894

\section{Paul, Abiodun Babatunde}

Department of Bioentrepreneurship and Training Services, Bioresource Development Centre, Ilorin, Nigeria.

Abiodun.babarinde@yahoo.com .,Phone: +2347036074340

\section{Abstract}

The study examined the effect of value addition on farm income of sweet potato-based farmers in Kwara State, Nigeria. A three-stage sampling procedure was employed to select 145 respondents. Structured questionnaire coupled with interview schedule were used to collect primary data. Multiple regression was used to analyse the effect of different value addition activities on income received from sweet potatoes. Also, marginal effects were obtained to analyse the effect of each independent variable separately on income. Findings revealed that farmers who engaged in value adding activities had higher income than those that sell at farm gate. In addition, farmer marketing groups had a stronger bargaining power in the market compared to farmers selling individually. The major factors influencing farm income of sweet potato based farmers are; access to trainings, family size, farm size and the stages of value addition. The ministry of agriculture through the ADPs should work more closely with the research and training institutes in the country to sensitize farmers on the need to form more farmer groups or join the different developmental programmes of government. Through these groups, useful information about trainings on new vine varieties, value addition, prices and limitless market opportunities are disseminated.

Keywords: Value addition, income from sweet potato 
Creative Commons User License: CC BY-NC-ND

Abstracted by: EBSCOhost, Electronic Journals Service (EJS), Google Scholar, Journal Seek, Scientific Commons,

Food and Agricultural Organization (FAO), CABI and Scopus
Journal of Agricultural Extension

Vol. 23 (4) October, 2019

ISSN(e): 24086851; ISSN(Print); 1119944X

http://journal.aesonnigeria.org

http://www.ajol.info/index.php/iae

Email: editorinchief@aesonnigeria.org

http://eoi.citefactor.org/10.11226/v23i4

\section{Introduction}

Sweet potato (Ipomea batata L.) has a long time history of being an important traditional crop grown by small-scale farmers majorly for household consumption. Often referred to as a "poor man's crop," because it is usually grown and consumed by resource poor households, and mainly by women. It also gives satisfactory yields under unfavourable climatic and soil conditions, as well as under low or non-use of external inputs (Getachew \& Jens, 2018). It is of strategic importance in the agricultural production of Sub-Saharan Africa, covering about 3.2 million hectares with a production estimate of 13.4 million tons of tubers (Faostat, 2015). Unlike many other crops, sweet potato grows easily, matures faster (4-5 months), have the capacity to produce food in abundance in relation to the space used for production and stores more or less well.

Sweet potato is well regarded in Nigeria as an important staple food crop. It is one of the starchy crops that are generally consumed throughout the country as an energy giving food. On dry matter basis, the non-carbohydrate macronutrient composition of the edible tuberous roots includes the following: 1.3 to $8.3 \%$ protein, 1.4 to $6.1 \%$ ash, 0.4 to $1.8 \%$ lipid and 3.4 to $5.9 \%$ crude fibre (Monday et. al., 2017). Sweet potato can play a very important role in food security strategy for Nigeria since it is drought resistant, it is a relatively short term crop with flexible time of harvest allowing a high degree of flexibility in food security strategy and it also improves the yield of maize in a crop rotation compared to continuous maize production (Ubwa et al., 2015). Research has shown that rotating sweet potato with maize improves farmers' incomes through higher yields of maize as well as income from sweet potato (Odendo and Ndolo, 2012).

However, the uses of sweet potatoes have been diversified considerably over the last two decades, having great potential as a source of local value-added products and as ingredients in other production processes. Value addition is the process of changing or transforming a commodity from its original state to a more valuable product. Value addition may take various forms that could be summarized in three stages to include: Primary processing such as proper cleaning, sorting, grading and packing sweet potato raw tubers for sale. This is the most common type of value addition practiced by farmers. Also, there is the secondary processing and this entails steaming, boiling or roasting the raw tubers. In addition, it can also take the form of grinding sweet potatoes into flour and packing the flour into different forms. The third stage entails high end processing and this involves activities such as frying sliced root tubers to obtain potato chips, noodles, candy, desserts. In addition, it involves baking breads, buns, cakes and doughnuts using sweet potato flour, preparing mandazi and chapatti using the same grinded flour or making sweet potato juice. This level also involves actual packaging of processed sweet potato products, branding, and marketing (Alice et. al., 2016).

The quest for agricultural value addition initiatives might be viewed as a key reaction to the expanded pressure in sweet potato production. Many farmers want to increase profitability, and value addition is one approach to achieve that objective. Value 
Creative Commons User License: CC BY-NC-ND

Abstracted by: EBSCOhost, Electronic Journals Service (EJS), Google Scholar, Journal Seek, Scientific Commons,

Food and Agricultural Organization (FAO), CABI and Scopus
Journal of Agricultural Extension

Vol. 23 (4) October, 2019

ISSN(e): 24086851; ISSN(Print); 1119944X

http://journal.aesonnigeria.org

http://www.ajol.info/index.php/iae

Email: editorinchief@aesonnigeria.org

addition initiatives have a specific significance in that it offers a technique for changing an unbeneficial enterprise into a productive one since utilization of value addition initiatives are the drivers of profit maximization in sweet potato production. The aim of the study was to examine the factors influencing level of income of farmers from sweet potato production.

\section{Methodology}

The study was conducted in Kwara State, Nigeria. The state is located within the North Central zone of Nigeria, sharing boundary with Ondo, Osun, Oyo, Ekiti, Kogi and Niger State in Nigeria and an international border with the Republic of Benin along its north-western part (Adeyonu et al, 2016) The state which lies between latitudes $7^{\circ} 45^{\prime} \mathrm{N}$ and $9^{\circ} 30^{\prime} \mathrm{N}$ and longitudes $2^{\circ} 30^{\prime} \mathrm{E}$ and $6^{\circ} 25^{\prime} \mathrm{E}$ has two distinct seasons (the wet and dry seasons). Kwara state has sixteen (16) local government areas (LGAs) and is primarily agrarian with a vast arable land and rich fertile soils. The state is classified into four (4) agricultural zones - A, B, C and D based on their agronomic uniqueness.

A three-stage sampling procedure was employed in the selection of respondents. The first stage involves a purposive selection of Zone D of Kwara ADP administrative zone. The zone was purposively selected based on the prevalence of sweetpotato production by virtually every household in many of the communities. Offa and Oyun LGAs (Zone D) were the major Sweetpotato producing areas in Kwara state accounting for about $70 \%$ of Sweetpotato output in the state in 2010 (KSMANR, 2010). The second stage also involves a purposive selection of three (3) local government areas (Offa, Oyun and Oke-ero) from Zone D Agricultural zone of Kwara state. The choice of LGAs was based on the volume of production of sweetpotato, and accessibility. The third stage involves the use of systematic random sampling method to select $40 \%$ of farming households from the list of sweetpotato farmers obtained from the state ADPs in the study areas. This makes a total sample size of One hundred and forty-five (145) respondents. Primary data were used for this study and were collected through the use of a structured questionnaire coupled with interview schedule.

Multiple regression models were used to determine the effect of activities at different stages of value addition on net farm income from sweet potatoes. In addition, the study analyzed the effect of key socio economic and institutional factors on income received from value added sweet potatoes. Marginal effects were also calculated.

The model was specified as:

$Y=\beta 0+\beta 1 X 1+\beta 2 X 2+\beta 3 X 3+\ldots \ldots \ldots \ldots \ldots \ldots+\beta n X n+v$ ................................ (1)

$Y=\beta o+\beta 1$ Acrgswtpot $+\beta 2$ schlnyrs $+\beta 3 /$ l11valueaddtn $+\beta 4$ Ivl2valueaddtn $+\beta 5$ Ivl3valueaddtn $+\beta 6$ hhsize $+\beta 7$ transportncosts $+\beta 8$ extnacc $+\beta 9$ attendtraing +

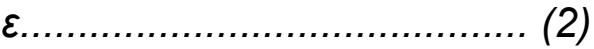


Creative Commons User License: CC BY-NC-ND

Abstracted by: EBSCOhost, Electronic Journals Service (EJS), Google Scholar, Journal Seek, Scientific Commons,

Food and Agricultural Organization (FAO), CABI and Scopus
Journal of Agricultural Extension

Vol. 23 (4) October, 2019

ISSN(e): 24086851; ISSN(Print); 1119944X

http://journal.aesonnigeria.org

http://www.ajol.info/index.php/iae

Email: editorinchief@aesonnigeria.org

Table 1: Description of variables used in the regression model

Variable code Variable Measurement of the variable Expected sign

Net Income (Y) Net income Net income from sweetpotato solely +

Swtpot. Acrg. Acreage under Total acreage (continuous) Sweetpotato

Literacy level Schooling years

No. of schooling years (continuous) +

Stg 1 valaddn stage 1 value addition

Level one $(\mathrm{Yes}=1, \mathrm{No}=0)$

Stg 2 valaddn stage 2 value addition

Stg 3 valaddn stage 3 value addition

Level two $(\mathrm{Yes}=1, \mathrm{No}=0)$

Level three $(\mathrm{Yes}=1, \mathrm{No}=0)$

Hsize

Household size Total number of householdmembers(continuous)

Transcost Total transport cost Total transport cost incurred to the market

(Continuous)

Extnaccs Access to Ext. Serv. Access to Extension ( $\mathrm{Yes}=1, \mathrm{No}=0)$

Attendtraing Attend training

Attend trainings $(\mathrm{Yes}=1, \mathrm{No}=0)$

+
+
+
+
+
+
+
+
+
+

\section{Result and Discussion}

\section{Factors Affecting Farmers' Income}

Factors that influenced the level of income that farmers obtained from the sale of raw and value added sweet potatoes are presented in Table 2. Six factors were found to have a significant effect on the farmers' level of income derived from the sale of sweet potatoes.

The adjusted $\mathrm{R}^{2}$ in the regression was $64 \%$, which implied that sixty-four percent of the variation in household revenue from sweet potatoes is explained by the independent variables.

Table 2: Factors affecting farmers' income.

\begin{tabular}{|c|c|c|c|}
\hline Variable & $d y / d x$ & Std. Err. & $z$ \\
\hline Farm size & $0.372^{\star \star \star}$ & 0.061 & $6.520^{*}$ \\
\hline Literacy level & -0.009 & 0.035 & -0.286 \\
\hline Access to extension services & 0.048 & 0.189 & 0.241 \\
\hline Age & 0.081 & 0.261 & 0.121 \\
\hline Transportation costs & -0.011 & 0.059 & -0.610 \\
\hline Family size & $0.473^{\star *}$ & 0.202 & $3.452^{*}$ \\
\hline Trainings attended & $0.340^{\star *}$ & 0.218 & $2.810^{*}$ \\
\hline Stage 1 value addition & $0.631^{* *}$ & 0.341 & $1.870^{*}$ \\
\hline Stage 2 value addition & $1.399^{\star \star \star}$ & 0.361 & $3.798^{*}$ \\
\hline Stage 3 value addition & $1.789^{\star \star \star}$ & 0.352 & $5.789^{*}$ \\
\hline Household size & 0.019 & 0.015 & 0.763 \\
\hline
\end{tabular}

${ }^{*} \mathrm{P} \leq 0.05$ 
Creative Commons User License: CC BY-NC-ND

Abstracted by: EBSCOhost, Electronic Journals Service (EJS), Google Scholar, Journal Seek, Scientific Commons,

Food and Agricultural Organization (FAO), CABI and Scopus
Journal of Agricultural Extension

Vol. 23 (4) October, 2019

ISSN(e): 24086851; ISSN(Print); 1119944X

http://journal.aesonnigeria.org

http://www.ajol.info/index.php/iae

Email: editorinchief@aesonnigeria.org

Marginal effect reveals the effect of one unit change in an independent variable on household revenue. From the estimated marginal effect results, six of the variables were found to be significant at different levels of confidence.

The farm size under which sweet potato is cultivated was found to be statistically significant at $1 \%$ implying that holding all other variable constant, $1 \%$ increase in farm size would lead to an increase in the household's farm income (Table 2). The corresponding marginal effect showed that one-unit increase in the farm size under sweet potato cultivation led to the household income increasing by $37.2 \%$. A greater farm size under sweet potato may translate to a higher output. Large scale production encourages farmers to channel their efforts and resources towards adding value at different levels while also comparing prices in the market across the different value addition levels. It was assumed that if the farm size under cultivation of sweet potato increases, the total incomes would also increase. This result was consistent with that of Akteruzzaman and Parvin, (2012) that farm size had a significant effect on farm income. The result also tallies with the work of Alice et. al., (2016) who reported similar trend in their study.

The regression coefficients of family size shows that increase in family size would lead to increase in the farming status of the household. This means that $1 \%$ increase in family size will increase the household's income. The results are expected because the faming households have a perception that the addition of one working member in a family enhances farm operations thereby increasing farm production and ultimately increasing household income.

Stage one value addition was statistically significant at $5 \%$. This implied an extra effort of activity under this level increased the household income by $63.1 \%$ compared to farmers who were not adding any value. The difference in prices among these two groups could have been attributed to the actual activities of sorting, grading, cleaning and packing done by farmers carrying out stage one value addition. The increase in household income will be as a result of extra activities the farmers are involved in which will improve the value of the produce for good marketability, as end users are expected to pay more due to the value added to the crop.

Stage two value addition was statistically significant at $1 \%$. This form of value addition had a positive effect on income. The more value a farmer adds, the higher the income earned at this stage. These implied farmers who were adding value at stage two improved their incomes by about $140 \%$. The diverse range of products due to value addition reaches the larger market leading to a significant increase in income. The result is in agreement with Umeh, 2013 which state that some cassava value added products have greater income generation advantage over other domestically.

Farmers carrying out activities in the highest level of value addition recorded highest improvement in their income. Stage three value addition was statistically significant at $1 \%$. This means that the more the value added to the raw tubers at this level, the higher the household income in geometric rate when compared with the current income. Aniedu et. al., (2014) indicated the high acceptability and good competitiveness of the sweet potato baked products, especially in small urban trading 
Creative Commons User License: CC BY-NC-ND

Abstracted by: EBSCOhost, Electronic Journals Service (EJS), Google Scholar, Journal Seek, Scientific Commons,

Food and Agricultural Organization (FAO), CABI and Scopus
Journal of Agricultural Extension

Vol. 23 (4) October, 2019

ISSN(e): 24086851; ISSN(Print); 1119944X

http://journal.aesonnigeria.org

http://www.ajol.info/index.php/iae

Email: editorinchief@aesonnigeria.org

centres close to the sweet potato production noting that products containing cooked and mashed sweet potato were exceptionally highly accepted by consumers who expressed a high level of willingness to pay the same price for sweet potato products as for similar products they have been buying.

Transportation costs was found to be insignificant. This is because costs are known to have a negative impact on income. These results align with that of Valenzuela and Velenzuela and Anderson (2014) who revealed that high transaction costs increased the poverty level in the rural areas as a result of reduced farmer incomes. These results however negate the findings of Alice et. al., (2016), who found out that transportation cost was statistically significant at $1 \%$ stating that the higher the transport costs incurred by a farmer, the higher the household income from sweet potato. The explanation for this was that the transportation cost was being charged per sack hence the more the output the more the sacks and consequently the higher the transportation cost. More output when sold was translating to higher income.

Attending trainings, no doubt determines the extent of farmer's involvement in value adding activities. Table 2 shows that training was statistically significant at $5 \%$. Farmers who had attended some form of training on value addition improved their incomes by up to $34 \%$ compared to those who had no training at all. The result is in consonance with Orinda (2013), that a direct association exist between training and farmers' decision to add value to SWP. The training by the farmers exposes them to different technology which they use in processing and packaging of sweet potato and therefore have a resultant effect on their productivity.

\section{Conclusion and Recommendation}

Trainings attended, family size, farm size and the stages of value addition were the major factors influencing farm income from sweet potato value addition. The ministry of agriculture through the ADPs should work more closely with the research and training institutes in the country to sensitize farmers on the need to form more farmer groups or join the different developmental programmes of government. This is because through these groups, useful information about trainings on new vine varieties, value addition, prices and limitless market opportunities are disseminated and loans are easy accessible. Also, farmer training in form of workshops, seminars and farmer field days should be encouraged so as to enable farmers exchange ideas on how to add value to their sweet potato and learn from each other while at the same time encouraging them to produce more so as to take advantage of economies of scale. 
Creative Commons User License: CC BY-NC-ND

Abstracted by: EBSCOhost, Electronic Journals Service (EJS), Google Scholar, Journal Seek, Scientific Commons,

Food and Agricultural Organization (FAO), CABI and Scopus
Journal of Agricultural Extension

Vol. 23 (4) October, 2019

ISSN(e): 24086851; ISSN(Print); 1119944X

http://journal.aesonnigeria.org

http://www.ajol.info/index.php/iae

Email: editorinchief@aesonnigeria.org

\section{References}

Adeyonu A.G., Ajala, A.O., Adigun, G.T., Ajiboye, B.O. and Gbotosho, O.O., 2016. Determinants of sweet potato value addition among smallholder farming households in kwara state, Nigeria. Agro-Science Journal of Tropical Agriculture, Food, Environment and Extension Volume 15 Number 1 January, 2016 pp. 17-22. ISSN 1119-7455

Akteruzzaman and Parvin, (2012). Factors affecting farm and non-farm income of HAOR Inhabitants of Bangladesh. Accessed on $11^{\text {th }}$ August, 2018.

Alice A.Oluoch, Job K. Lagat Jackson Langat (2016). Evaluation of effects of value addition in sweet potatoes on farm income in Homa, bay County, Kenya. Journal of Economics and Sustainable Development. Vol.7, No.20, 2016. ISSN 2222-1700 (Paper) ISSN 2222-2855 (Online). www.iiste.org

Aniedu, C., Aniedu, O. C., and Nwakor, N. (2014). Impact and Adoption of Value Added Innovations in Root and Tuber Crops among Farmers in Imo State, Nigeria. Global Journal of Science Frontier Research Agriculture and Veterinary Sciences, 12: 1-7

Food and Agriculture Organization Corporate Statistical Database, (2015). Pig stocks in sub-Saharan African countries in. www. Faostat.fao.org. Last accessed $12^{\text {th }}$ June2017.

Getachew S and Jens B. A (2018). Sustainability of Improved Crop Varieties and Agricultural Practices: A Case Study in the Central Rift Valley of Ethiopia. Agriculture $177 \mathrm{pp}$.

Kwara State Ministry of Agriculture and Natural Resources (2010). Report of Kwara State Farmers' Census. 55 pp.

Monday Abel Otache, Simon Terver Ubwa and Agbajor Kparobo Godwin (2017). Proximate Analysis and Mineral Composition of Peels of Three Sweet Cassava Cultivars. Asian Journal of Physical and Chemical Sciences 3(4): 1-10, 2017; Article no.AJOPACS.36502. ISSN: 2456-7779

Odendo M. and Ndolo P.J. (2012). Impact of improved sweet potato varieties in western Kenya:Farmers'Perspectives.http://www.fao.org/docs/eims/upload/agrotech/2009/R 8299_FTR.pdf (Accessed on 3rd March, 2017)

Orinda, M.A. (2013). Analysis of factors Influencing Sweet Potato Value Addition amongst Smallholder Farmers in Rachuonyo South District, Kenya. (MSc Dissertation) Retrieved from ir-library.egerton.ac.ke

.Ubwa S.T, Otache M.A, Igbum G.O, Shambe T. (2015). Determination of cyanide content in three sweet cassava cultivars in three local government areas of Benue State, Nigeria. Food and Nutrition Sciences. 2015;6:1078- 1085. Available:http://dx.doi.org/10.4236/fns.2015.612112

Umeh G.N., 2013. Effect of cassava value addition on the income generation of farm households in Etinam Local Government Area of Akwa Ibom State, Nigeria. International Journal of Science and Research (IJSR). ISSN (Online): 2319-7064.

Valenzuela, E., and K. Anderson. (2014). "Alternative Agricultural Price Distortions for CGE Analysis of Developing Countries, 2004 and 1980-84." Research Memorandum 13 (December), Center for Global Trade Analysis, Department of Agricultural Economics, Purdue University, West Lafayette,IN.https://www.gtap.agecon.purdue.edu/resources/res_display.asp?

RecordID=2925. 